\title{
Association of acute local reactions to insulin with an insulin-binding gamma I $\mathrm{M}$ antibody
}

\author{
J. G. DEVLIN' ${ }^{1}$ AND D. K. O'DONOVAN
}

From the Department of Medicine and Therapeutics, University College, Dublin

SYNOPSIS Sera from 15 diabetic patients treated with insulin for periods varying from four week to 19 years and from two control subjects were investigated for the presence of insulin $\mathbf{I}^{131}$-binding antibody. It was found in all patients even as early as four weeks after the initiation of therapy, but the antibody in the gamma I M region was found in only one, the only patient who had severev local reactions to insulin at the time when the serum was being collected. It is suggested that the acute local reactions to insulin are due to the development of a transient gamma I M insulin? binding antibody.

Twenty-five per cent of all diabetics receiving insulin develop at one stage or another local skin reactions to insulin (Joslin, Root, White, and Marble, 1959; Arkins, Engbring, and Lennon, 1962). One of the most frequently occurring local reactions develops within a few days after insulin therapy being initiated and subsequently subsides (Paley and Tunbridge, 1952; Marble and Cahill, 1962). The reaction consists of local tenderness, redness, swelling, and pain and suggests an allergic response. There is still controversy as to whether this is due to an allergic response to an impurity in the commercial insulin used or to the crystalline insulin itself. The local reaction can be controlled by the addition of small amounts of hydrocortisone to the insulin but antihistamine drugs are ineffective whether given locally or orally (O'Donovan and MacCormac, 1961).

This investigation shows that the acute local reaction is associated with the presence of an insulinbinding gamma I $\mathbf{M}$ antibody which is not present in the general diabetic population receiving insulin.

\section{MATERIALS, METHODS, AND CLINICAL DETAILS}

Sera from 15 diabetic patients and two healthy control subjects were studied. The age, sex, insulin dosage, and duration of insulin therapy at time of venupuncture of each patient are set out in Table I. Patient no. 6 is of special interest.

C.R., aged 47, weight 129 lb., was admitted for investigation of diabetes of recent onset. The fasting blood sugar level was $225 \mathrm{mg}$. \%. Acute local reactions developed two weeks after the commencement of insulin 'Wellcome Trust research fellow. Received for publication 1 September 1964.
TABLE I

AGE, SEX, INSULIN DOSAGE, DURATION OF THERAPY, AND HAEMAGGLUTINATION ANTIBODY TITRES OF 15 PATIENTS STUDIED

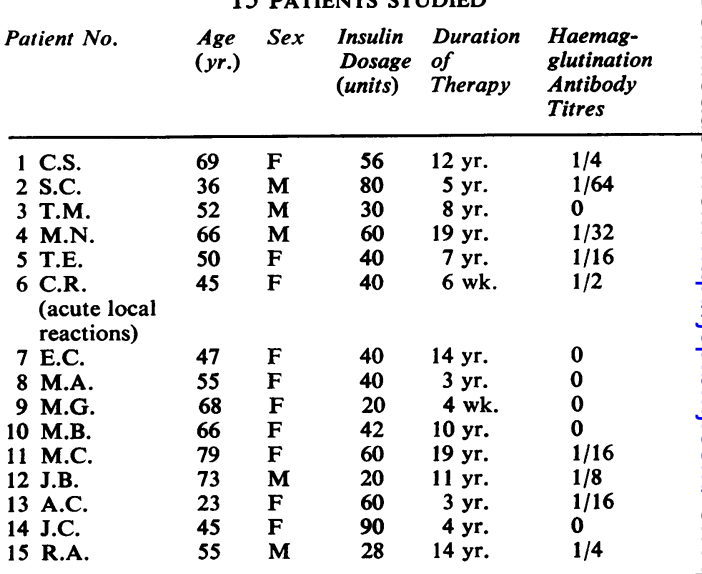

therapy and subsided after a further three weeks. She had never had any evidence of a generalized allergic reactios such as urticaria, eosinophilia, fever, or asthma. The patient gained $4 \mathrm{lb}$. while in hospital. She was re-admitted eight months later with an ovarian carcinoma from whick she died within two months.

In all the cases insulin antibody titres were determine by the tanned red-cell method of Boyden (1951) as modified by Moinat (1958). Insulin immuno-globuliq patterns were studied by radioimmunoelectrophoresis (Morse and Heremans, 1962; Yagi, Maier, and Pressmant 1962). Antihuman serum was obtained from Hylan\& Laboratories, L.A., and specific anti gamma I $\mathbf{M}$ an $\$$ anti gamma I A antisera were donated by Dr. J. Fahey N.I.H., Bethesda. Insulin $I^{181}$ was obtained from Abbof 
Laboratories (specific activity $36.7 \mathrm{mc} . / \mathrm{mg}$.). This was further purified according to the method of Banerjee and Gibson (1962) and the subsequent chromatogram was scanned in a Baird and Tatlock radioactive chromatogram counter. The insulin $\mathrm{I}^{\mathbf{1 3 1}}$ used contained only $3.9 \%$ impurities. Sera and insulin $I^{131}$ were incubated at $4^{\circ} \mathrm{C}$. for four days before agar-gel electrophoresis.

All sera were tested for precipitin antibodies to insulin in Agar Noble and in Ionagar.

\section{RESULTS}

Insulin $\mathrm{I}^{131}$-binding antibody was present in all the diabetic sera tested. The pattern of the autoradio-

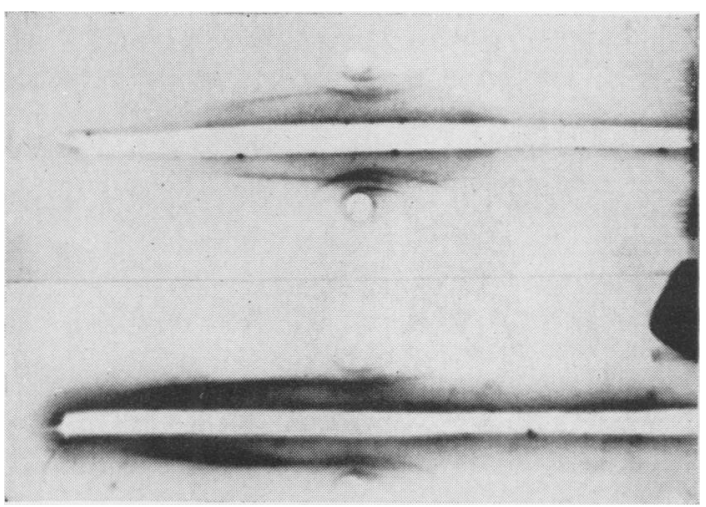

FIG. 1 .

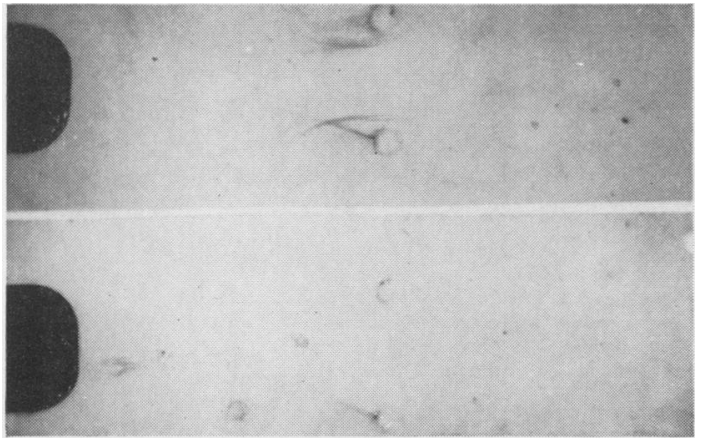

FIG. 2.

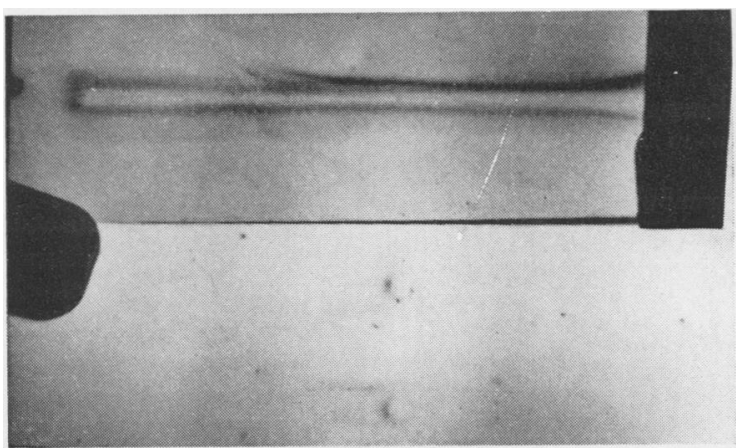

FIG. 3 . graphic lines obtained is demonstrated in Figure 1. The 7S gamma globulin line is reproduced in its full extent. There is also some non-specific staining of the alpha 2 macroglobulin precipitin line which also occurs in the control sera using total antihuman serum (Fig. 2). There was no non-specific staining of the control sera with the specific antisera.

The autoradiographic line obtained from the serum of patient C.R. shows a well-marked curve and an increased density in the region of the starting well (Fig. 3). Good precipitin lines were obtained with the specific antibeta $2 a$ antiserum but no insulin binding could be demonstrated (Fig. 4).

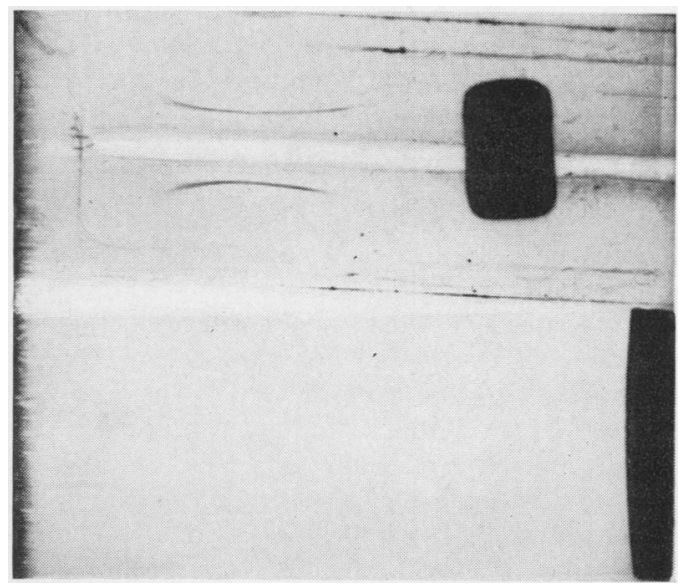

FIG. 4.

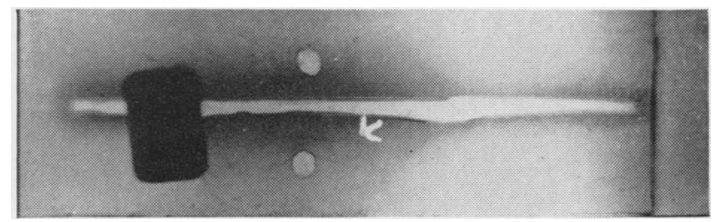

FIG. 5 .

FIG. 1. Pattern of autoradiographic line obtained in diabetic sera. Radioactivity is found in the $7 S$ gamma globulin precipitin lines and in the alpha 2 macroglobulin precipitin line.

FIG. 2. Non-specific staining of the alpha 2 macroglobulin precipitin lines in control sera.

FIG. 3. Autoradiographic lines obtained from patient's (C.R.) serum.

Upper line $=$ whole antihuman serum.

Bottom line = specific anti-gamma I M antiserum.

FIG. 4. Anti-beta $2 A$ preciptin lines and negative testing for radioactivity.

FIG. 5. Gamma I $M$ precipitin lines. 
The precipitin lines obtained with the specific antigamma I $M$ were much fainter (Fig. 5). but were present in all sera tested. Insulin binding was demonstrated in the gamma I M immunoglobulin in the serum from the patient C.R. only (Fig. 3).

There was no relationship between haemagglutination antibody titre and the presence of this gamma I $\mathrm{M}$ antibody (Table I).

No demonstrable precipitin antibodies to insulin were present in any of the sera tested.

\section{DISCUSSION}

The natural history of the acute local reaction suggests that it is an allergic phenomenon. The fact that it could be partly or completely controlled in some cases by using heated insulin (Dolger, 1952) suggested that some impurity in the insulin was responsible although partial degradation of the insulin molecule with alteration of immunological response could not be ruled out. The presence of a gamma I $\mathbf{M}$ insulin-binding antibody in the serum of the patient C.R. strongly suggests that this antibody was responsible for the local reaction and is supported by the absence of an insulin-binding gamma I $M$ antibody in the serum of patient no. 9 who did not have an acute local reaction at a time when a macromolecular antibody could be expected (Svehag and Mandel, 1964). Also two patients (cases 2 and 3), who had acute local reactions when insulin therapy was initiated, now have no local reactions and screening for gamma I $\mathbf{M}$ antibody was negative.

The nature of skin-sensitizing antibodies has not been fully elucidated although the subject has been reviewed by Sehon (1963) and by Stanworth (1963). There is some evidence that the three classical immunoglobulins, viz., gamma I $\mathbf{M}$, gamma I A, and $7 \mathrm{~S}$ gamma globulin, may play a part. It is accepted, however, that passive cutaneous transfer reactions are not readily demonstrable with macromolecular antibodies. So far in this study all Prausnitz-Küstner reactions have been negative. Previous studies of insulin immunoglobulin patterns have not included specifically patients with acute local reactions. Loveless and Cann (1955) found a antibody in the beta region in one allergic diabetic. patient. Yagi, Maier, Pressman, Arbesman, Reisman and Lenzner (1963) found an insulin-binding antibody in the gamma I $M$ and gamma I A regiof in one out of 23 diabetic sera investigated. Thei patient had generalized insulin allergy with eosino philia, urticaria, and a positive Prausnitz-Küstne? reaction. Miller and Owen (1960) and Harris-Joneș Miller, and Owen (1963) found insulin-binding $\vec{s}$ antibody in the beta globulin region but clinicat details relating to the presence or absence of acutej local reactions were not stated. Morse and Heremans? (1962) failed to find other than 7S gamma globulin insulin-binding antibody in the sera of eight diabetico patients. The present study confirms the presence्w of 7S gamma antibody to insulin in diabetic seran and records the association of a gamma I M insulino binding antibody with acute local reactions to insulin.

This work has been supported in part by the Medical Research Council of Ireland. The technical assistance of A. Hickey is much appreciated.

\section{REFERENCES}

Arkins, J. A., Engbring, N. H., and Lennon, E. J. (1962). J. Allerg 33, 69.

Banerjee, R. N., and Gibson, K. (1962). J. Endocr., 25, 145.

Boyden, S. V. (1951). J. exp. Med., 93, 107.

Dolger, H. (1952). N.Y. State J. Med., 52, 2023.

Harris-Jones, J. N., Miller, H., and Owen, G. (1963). J. clin. Path 16, 120.

Joslin, E. P., Root, H. F., White, P., and Marble, A. (1959). The Treatment of Diabetes Mellitus, 10th ed. Lea and Febiger Philadelphia.

Loveless, M. H., an 1 Cann, J. R. (1955). J. Immunol., 74, 329.

Marble, A., and Cahill, G. F. (1902). The Chemistry and Chemoe therapy of Diabetes Mellitus, p. 119. Thomas, Springfield Illinois.

Miller, H., and O ven, G. (1960). Nature (Lond.), 188, 67.

Moinat, P. (1958). Diabetes, 7, 462.

Morse, J. H., and Heremans, J. F. (1962). J. Lab. clin. Med., 59, $891 \frac{7}{7}$ O'Donovan, D. K., and MacCormac, M. (1961). 4e Congrès de lầ Fédération Internationale du Diabète, vol. 1, p. 591. Editiong Médecine et Hygiène, Genèva.

Paley, R. G., and Tunbridge, R. E. (1952). Dicbetes, 1, 22.

Sehon, A. H. (1963). Brit. med. Bull., 19, 183.

Stanworth, D. R. (1963). Ibid., 19, 235.

Svehag, S.-E., and Mandel, B. (1964). J. exp. Med., 119, 1 et seq. O Yagi, Y., Maier, P., and Pressman, D. (1962). J. Immunol., 89, 736. - - - - - Arbesman, C. E., Reisman, R. E., and Lenzner? A. R. (1963). Ibid., 90, 760. 